\title{
Relation of complementary foods and anemia in urban underprivileged children in Surakarta
}

\author{
Endang Dewi Lestari, Annang Giri Moelya, Elief Rohana, Budiyanti Wiboworini
}

\begin{abstract}
Background Iron deficiency anemia (IDA) is still prevalent in Indonesian children. Attempt to treat patients with IDA with iron supplementation has been difficult because of low compliance.

Objective To determine the complementary foods that contributes in the prevalence of anemia in children.

Methods A cross sectional study was conducted in three urban underprivileged villages. Healthy children aged 6-23 months at the time of interview were selected. The questionnaire was specially developed for determining the risks of IDA. We took blood sampling to measure the hemoglobin concentration.

Results A total of 86 children participated in the study; but only data of 78 children were available for analysis. The prevalence of anemia among those children was 35\%. Most children (90\%) consumed animal protein inadequately. Rice-based diet was the main meal of most children (97\%). Analysis of possible factors associated with the anemia showed that inadequate plant or animal protein consumption, wasted children, less than 2 orange consumption, not consuming iron fortified formula/cereal had OR 1.2 (95\%CI 0.40; 3.61), 4.13 (95\%CI 0.48;35.45), 4.67 (95\%CI 1.04;20.04), 6.25 (95\% CI $1.32 ; 29.55)$ and 3.15 (95\%CI 1.18;8.41), respectively. Logistic analysis revealed that the factors associated with anemia were wasted children (OR 9.10, 95\%CI 1.38;60.18), low or no orange consumption (OR $7.86,95 \% \mathrm{CI} 1.36 ; 45.40$ ) and not consuming iron fortified formula/ cereal (OR 3.01, 95\%CI 1.02;8.90).

Conclusion In children with rice-based diet as main meal, consuming orange as an enhancing factor should also be addressed in order to prevent anemia. [Paediatr Indones 2007;47:196-201].
\end{abstract}

Keywords: complementary food, iron deficiency, anemia

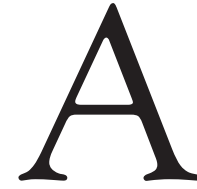

nemia is considered to be a late manifestation of iron deficiency; ${ }^{1}$ this may cause long-term psychomotor, behavioral, and developmental effects. ${ }^{2-5}$ Most of health personnel responsible in taking care the children are aware that iron deficiency is the most frequent cause of anemia in children, ${ }^{6}$ that can be prevented by feeding the child with food or fortified food containing iron. ${ }^{7-9}$ The prevalence of anemia in children in developing country is high. ${ }^{10,11}$ In the United States, aproximately $9 \%$ children aged $1-2$ years are iron deficient, ${ }^{12}$ and in Israel, $15.5 \%$ infants were iron deficient. ${ }^{13}$ Giving iron during the first years of life is an important approach to prevent IDA in high risk children, ${ }^{1,6,14,15}$ but multivitamin with iron is not effective in preventing IDA in infants aged 9-months old. ${ }^{16}$ Moreover, supplementation of iron liquid in children is not easy and the compliance has been consistently low. ${ }^{17-19}$

Presented at the Annual Scientific Meeting IDAI, Yoyakarta, Indonesia, May 6-9, 2007.

From The Department of Child Health, Medical School, University of Sebelas Maret, Moewardi Hospital, Surakarta, Indonesia.

Reprint Requests to: Endang Dewi Lestari, MD, Division of Pediatric Nutrition and Metabolic Disease, Department of Child Health, Medical School, University of Sebelas Maret, Moewardi Hospital, Surakarta, Indonesia. Email: tarndang@yahoo.com. 
Iron deficiency may result from low intake of the sources of dietary iron, high intake of inhibitors of iron absorption, and low intake of enhancers of iron absorption. ${ }^{6,20,21}$ In most of low income people in developing countries, the main meals are porridge and rice-based diets which contain low amount of iron and thus increase the risk of iron deficiency. ${ }^{11}$ The objective of this study was to determine complementary foods that contribute in increasing the prevalence of anemia in children at the age of 6 23 months at urban underprivileged villages in Surakarta.

\section{Methods}

This was a cross sectional study conducted in three urban underprivileged villages at Surakarta, Central Java, Indonesia from May to September 2005. Sixty subjects would be needed for multivariate analysis.

We included healthy 6-23 months old children without physical handicaps or dysmorphic features. The survey questionnaire was designed from the literature concerning factors that cause iron deficiency anemia in children. It was organized into domain for risk of iron deficiency anemia, particularly factors from complementary foods and the confounding factors such as the frequency of consuming animal protein (poultry, fish, meat) and plant protein (tofu, tempe, soybean, green bean, peanut), the frequency of consuming orange, the information about the consuming of daily formula/cereal fortification, body weight, body height, sex and age. Blood sampling was taken at the end of the whole examination. Children in whom hemoglobin level could not be assessed were excluded from analysis. Written informed consent was required for inclusion. The study was approved by the Ethical Committee of Medical School, Sebelas Maret University, Surakarta, Indonesia.

\section{Age and gender}

Age was calculated from the date of birth and rounded to the closest year, and then was grouped into 6-11 month and 12-23 month groups. Gender was recorded to be used for the calculation of nutrition status by using Epi Info version 3.3.2.

\section{Physical measurements}

Body weight and height of each child were measured by using the same standard protocol. A digital weighting scale for children below 2 years old (Tanita ${ }^{\circledR}$ Model 1380 Mechanical Baby Scale) was used to weigh the study subjects. Each subject was twice weighed naked or in light underwear which was later subtracted from the total weight, averaged to the nearest $0.1 \mathrm{~kg}$. The accuracy of the instrument was checked with a calibrated rule before and after each measuring session. Children's length was measured recumbent (crown-heel), averaged from three measurements, to the nearest $0.1 \mathrm{~cm}$. A locally constructed wood length-board with a rigid head board and a sliding foot-piece was used for this purpose.

\section{Nutrition status}

The body weight, body height and sex of the children were used to calculate nutritional status by using Epi Info version 3.3.2 to find out the Z-scores of the weight for height of the children. The results of the calculation of the Z-score $<-2$ were recorded as a wasted child.

\section{Collection of the diet information}

Three nutritionists interviewed the parents to obtain the information about the frequency of feeding the child with the sources of plant protein, animal protein, orange, and fortified formula/cereal in the daily living.

\section{Plant protein, animal protein, and orange consumption}

The frequency of plant protein consumption was collected from the history of tempe, tofu, ground nut, green nut, and soy bean (5 items) consumption, whereas the frequency of animal protein consumption was collected from egg, poultry, meat, fish, dry fish and shell (6 items) consumption. From those, each source obtained was graded into 7 points of frequency i.e. (0) never, (1) sometimes, (2) $1-2$ times/month, (3) 1 time/ week, (4) $>1$ time/week, (5) 1 time/day, (6) $>1$ time/ day. Using the same way, we obtained the frequency of orange consumption.

The maximal score for plant protein consumption was 30 for 5 items, and for animal protein con- 
sumption was 36 for 6 items. We defined infrequent plant protein consumption if the score of plant protein consumption was less than 20 points, whereas for infrequent animal protein consumption if the score was less than 24. In other words, consuming protein source infrequently was meant that the child did not consume the source of protein more than once a day.

\section{Formula/cereal fortification}

Information about the child daily consumption of fortified formula/cereal was recorded as "yes" if the parents revealed that the child had consumed any fortified formula/cereal from the factory.

\section{Blood sample}

EDTA-treated whole blood was used to measure hemoglobin level by the cyanomethemoglobin technique. A hemoglobin level of $<11 \mathrm{~g} / \mathrm{dL}$ was considered as anemia. Due to the limitation of the fund, we did not examine serum ferritin levels.

\section{Statistical analysis}

Epi Info version 3.3.2 was used to transform the body weight and the body height into Z-score of nutritional status. Risk factors for anemia were analyzed by using univariate and multivariate logistic regression with SPSS 12.0 for Windows. A P value of $<0.05$ was considered statistically significant.

\section{Results}

A total of 86 children aged 6-23 months participated in the study. We excluded 8 children who did not have the result of blood sample, leaving 78 children eligible for analysis, i.e, 34 aged 6-11 months and 44 aged 12-23 months. The proportion of wasted children was $11 \%$. Most children aged 6-23 months consumed plant protein and animal protein infrequently, but they consumed more plant protein than animal protein, i.e. $24 \%$ and $10 \%$, respectively. Most children in our series also consumed orange rarely; once a week or never. In the contrary, most of subjects (65\%) consumed the fortified formula/cereal fortification as additional food daily. However, the prevalence of anemia among children 6-23 months old was still high (35\%) (Table 1). Rice-based diet was still the main meal of most children in the study population (97\%).

Univariate analysis showed that wasted children, children who consumed orange once a week or never, and children who did not consume fortified formula/cereal daily were significantly associated with of anemia. Children who consumed infrequently plant protein and animal protein had 1.2 times and 4.1 times to have anemia respectively, but those figures were not statisically significant. Children aged 12 23 months had 1.5 times more often to be anemic than those of 6-23 months old (Table 2).

On multivariate analysis it was shown that the probability of wasted children to be anemic was 9 times more often than that of non-wasted children. Moreover, children who consumed orange once a week or never had 8 times risk to get anemia than children who consumed orange once or more per week. Consumption of fortified formula/cereal daily was also significantly associated with anemia (Table 3).

\section{Discussion}

Iron deficiency is the most common cause of anemia in infancy and childhood, characterized by a drop in serum feritin below $12 \mathrm{ng} / \mathrm{dL}$. The present study detects iron deficiency only by using hemoglobin examination. Yet, it supports that the determinants of complementary

Table 1. The baseline characteristics of the subjects $(n=78)$

\begin{tabular}{lcc}
\hline \multicolumn{1}{l}{ Characteristics } & $\mathrm{n}$ & $\%$ \\
\hline Age & & \\
6-11 months & 34 & 43 \\
12-23 months & 44 & 56 \\
Sex & & \\
$\quad$ Boy & 43 & 55 \\
$\quad$ Girl & 35 & 44 \\
Nutrition status & & \\
$\quad$ Wasted children (W/H <-2 SD) & 9 & 11 \\
Consuming plant protein & & \\
$\quad$ Frequently & 19 & 24 \\
$\quad$ Infrequently & 59 & 75 \\
Consuming animal protein & & \\
$\quad$ Frequently & 8 & 10 \\
$\quad$ Infrequently & 70 & 89 \\
Frequency of consuming orange & & \\
$\quad$ Once a week or more & 19 & 24 \\
$\quad$ Once a week or never & 59 & 75 \\
Consume fortified formula/cereal daily & 51 & 65 \\
Anemia (Hb <11 g/dL) & 27 & 34 \\
\hline
\end{tabular}


foods have important role in the prevalence of anemia in infants and young children. The increasing prevalence of anemia in infants and young children coincides with the increasing prevalence of bad habit in practicing complementary feeding. As in many developing countries, ${ }^{11}$ the major sources of complementary foods in infants and young children in this study population are rice-based diets (97\%) which contain low iron and other micronutrients.

To utilize the source of iron, there are several factors influencing the mechanism of utilization; two types of iron influence the absorption of the iron i.e. heme and non-heme iron. The effect of the composition of the diet is based on the type of iron in the diets, the amount of iron, food preparation, iron status of the children, and the balance between enhancing and inhibiting factors. Several foods/vitamins as enhancers are meat, poultry, fish, fermented foods, ascorbic acid. The inhibiting factors are phytate, polyphenol, calcium, and soy protein.

Our findings revealed that most infants and young children consume animal protein and enhancing factors (meat, poultry, fish) infrequently. Although the results of

Table 2. Univariate analysis of the possible factors associated with the prevalence of anemia $(n=78)$

\begin{tabular}{lccc}
\hline \multicolumn{1}{c}{ Factors } & OR & $P$ & $95 \% \mathrm{Cl}$ \\
\hline $\begin{array}{l}\text { Age } \\
12-23 \text { months }(n=44)\end{array}$ & 1.51 & 0.40 & $0.58 ; 3.93$ \\
$\begin{array}{l}\text { Nutrition status } \\
\text { Wasted children (W/H <-2 SD) } \\
(n=9)\end{array}$ & $4.67^{*}$ & 0.04 & $1.04 ; 20.04$ \\
$\begin{array}{l}\text { Consume plant protein } \\
\text { infrequently ( }=59)\end{array}$ & 1.20 & 0.75 & $0.40 ; 3.61$ \\
$\begin{array}{l}\text { Consume animal protein } \\
\text { infrequently }(n=70)\end{array}$ & 4.13 & 0.20 & $0.48 ; 35.45$ \\
$\begin{array}{l}\text { Consume orange once a week } \\
\text { or never }(n=59)\end{array}$ & $6.25^{*}$ & 0.02 & $1.32 ; 29.55$ \\
$\begin{array}{l}\text { Not consume fortified formula/cereal } \\
\text { daily }(n=27)\end{array}$ & $3.15^{*}$ & 0.02 & $1.18 ; 8.41$ \\
\hline
\end{tabular}

*Significant

Table 3. Multivariate analysis of significant factors associated with the prevalence of anemia $(n=78)$

\begin{tabular}{lccc}
\hline Factors & OR & $\mathrm{P}$ & $95 \% \mathrm{Cl}$ \\
\hline Wasted children (W/H < - 2 SD) & $9.10^{\star}$ & 0.02 & $1.38 ; 60.18$ \\
Consume orange once a week & $7.86^{*}$ & 0.02 & $1.36 ; 45.40$ \\
or never & & & \\
$\begin{array}{l}\text { Not consume fortification of } \\
\text { formula/cereal daily }\end{array}$ & $3.01^{*} 0.04$ & $1.02 ; 8.90$ \\
\hline
\end{tabular}

* Significant the $\mathrm{OR}$ in the present study were not significant; there was evidence that insufficient consumption of animal protein is a risk factor for anemia in infants and young children. In this population as well as in the other developing countries, rice-based diets was the main meal for children; only a small proportion of children consume animal protein. Thus the heme iron content of their daily diet is usually negligible. ${ }^{22}$ In fact, the average absorption of heme iron in meat containing meals is high; it is about $25 \%{ }^{23}$

Even though orange is not a source of iron, our finding showed that once a week or never consuming orange was associated with the prevalence of anemia. Orange is a source of ascorbic acid; as an enhancing factor, it contributes in increasing iron bioavailability of the child diets. It is already recognized that the percentage of iron bioavailability can vary from $<1 \%$ to $>50 \%{ }^{6}$ depends on many factors including the availability of enhancing factors.

Most children in the present study were fed with foods rich of heme iron (meat/poultry/fish) frequently. On the other hand, almost all of them were fed by using source of non-heme iron i.e. rice-based diets that also contain of phytate as inhibiting factor. They also consumed more non-heme iron from plant protein than heme iron (meat/poultry/fish). Iron absorption of nonheme iron can be enhanced by enhancing factors such as orange, vitamin C, etc. In Indonesia, it is easy to find orange everywhere and in every season. It seems that as an enhancing factor, orange has an important role in this population in contributing to the bioavailability of iron.

Infants and children who did not consume iron fortified formula/cereal daily were 3 times more often to develop anemia than those who did. Studies reveal that fortification of iron is effective in preventing iron deficiency anemia, and it should be considered to be implemented in the program for all risk children. ${ }^{24,25}$ However, rice-based diet is the main daily diet in infants and children. Iron fortified rice has been instituted in the Philippines, ${ }^{24}$ but is not ready for program implementation in most developing countries. 25

Wasted children was a significant risk factor for the delopment of anemia in infants and young children. Malnutrition in children in developing countries is mainly caused by insufficient dietary intake; malnutrition also causes depletion of body protein including the transferrin which is as a 
Endang Dewi Lestari, et al: Anemia and complementary foods on urban underprivileged children

transporter of iron. ${ }^{6,20,21}$ Furthermore, iron deficiency will damage mitochondria and causes oxidative stress. $^{26,27}$ It seems that insufficient dietary intake could play a role in secondary mitochondrial dysfunction $^{27}$ that contribute to measure the prevalence of undernutrition status in children.

Our findings support the importance of iron deficiency, as reflected by reduced hemoglobin production, as a big public health problem. Non-heme iron is as the main source of iron in our study; hence, it needs enhancing factors to increase the iron bioavailability. Besides the socialization for consuming more nutritious food as source of iron, socialization of consuming orange as enhancing factors should also be addressed in every occasion in order to prevent iron deficiency anemia among infants and young children. Fortified rice also should be considered. Further study, including longitudinal study, should determine the role and magnitude of quality and quantity of locally complementary foods on the incidence of iron deficiency anemia in Indonesia children. This is invaluable as an input to develop recommendations regarding the best and easiest way to prevent anemia among children.

\section{Acknowledgments}

We thank the Nutrition Unit of Moewardi Hospital, Surakarta (Agus Ismu Hartono, Henry, Wiwik) for their contribution in data collection. We also thank the staffs of Budi Sehat Laboratory who performed the blood sample examination and PT Pediatrica in supporting the study. And, most of all, we are indebted to the children and the parents who participated in the study.

\section{References}

1. World Health Organization. Nutritional anaemias: report of a WHO scientific group. Technical Report Series, no. 405. Geneva: WHO, 1968. Available from URL: http:// whqlibdoc.who.int/trs/WHO_TRS_405.pdf

2. Grantham-McGregor S, Ani C. A review of studies on the effect of iron deficiency on cognitive development in children. J Nutr 2001;131:S649-68.

3. Konofal E, Lecendreux M, Arnulf I, Mouren MC. Iron deficiency in children with attention-deficit/hyperactivity disorder. Arch Pediatr Adolesc Med 2004;158:1113-5.
4. Algarin C, Peirano P, Garrido M, Pizarro F, Lozoff B. Iron deficiency anemia in infancy: long-lasting effects on auditory and visual system functioning. Pediatr Res 2003;53:217-23.

5. Saloojee H, Pettifor JM. Iron deficiency and impaired child development. BMJ 2001;323:1377-8.

6. Center for Disease and Control Prevention. Recommendations to prevent and control iron deficiency in the United States. MMWR recomm Rep 1998;(RR-3):1-25.

7. Zlotkin S. Clinical nutrition: The role of nutrition in the prevention of iron deficiency anemia in infants, children and adolescents. CMAJ 2003;168:59-63.

8. Gokcay G. Strategies for the prevention of iron deficiency anaemia in children. J Trop Pediatr 2006;52:75-7.

9. American Academy of Pediatrics, Committee on Nutrition. Iron fortification of infant formulas. Pediatrics 1999; 104:119-23.

10. Yip R, Ramakrishnan U. Experiences and challenges in developing countries. J Nutr 2002;132:S827-30.

11. Zimmermann MB, Chaouki N, Hurrell RF. Iron deficiency due to consumption of a habitual diet low in bioavailable iron: a longitudinal cohort study in Moroccan children. Am J Clin Nutr 2005;81:115-21.

12. Center for Diseases Control and Prevention. Iron deficiencyUnited States, MMWR morbidity and mortality weekly report 2002.

13. Meyerovitch J, Sherf M, Antebi F, Barhoum-Noufi M, Horev $\mathrm{Z}$, Jaber $\mathrm{L}$, et al. The incidence of anaemia in an Israeli population: A population analysis for anemia in 34512 Israeli Infants aged 9 to 18 months. Pediatrics 2006;118:e1055-60.

14. Domellof M, Cohen FJ, Dewey KG, Hermell O, Rivera LL, Lonnerdal B. Iron supplementation of breastfed Honduran and Swedish infants from 4-9 months of age. J Pediatr 2001;138:679-87.

15. Lind T, Lönnerdal B, Stenlund H, Ismail D, Seswandhana S, Ekström EC, et al. A community-based randomized controlled trial of iron and zinc supplementation in Indonesian infants: interactions between iron and zinc. Am J Clin Nutr 2003;77:883-90.

16. Geltman PL, Meuers AF, Mehta SD, Brugnara C, Villon I, Wu YA, et al. Daily multivitamins with iron to prevent anemia in high-risk infants: a randomized clinical trial. Pediatrics 2004; 114:86-93.

17. Allen LH. Iron supplements: scientific issues concerning efficacy and implications for research and programs. J Nutr 2002;132: S813-9.

18. Amsel S, Boaz M, Ballin A, Filk D, Ore N. Low compliance of iron supplementation in infancy in relation to socioeconomic status in Israel. Pediatrics 2002;110:410-1. 
Endang Dewi Lestari, et al: Anemia and complementary foods in urban underprivileged children

19. Yip R. Iron supplementation: country level experiences and lessons learned. J Nutr 2002;132:S859-61.

20. Olivares M, Walter T, Hertrampf E, Pizarro F. Anemia and iron deficiency disease in children. Br Med Bull 1999;55:534-43.

21. Goddard WP, Murray I, Long RG, Scott B, Barton R, Salman M, et al. Iron deficiency anaemia. BMJ 1997;314:1759.

22. Olivares M, Hertrampf E, Pizarro F. Effect of iron stores on heme iron absorption. Nutr Res 1993;13:633-8.

23. Hallberg L, Bjorn-Rasmussen E, Howard L. Dietary heme iron absorption. A discussion of possible mechanisms for the absorption-promoting effect of meat and for the regulation of iron absorption. Scand J Gastroenterol 1979;14:769-79.
24. Mannar V, Gallego EB. Iron fortification: country level experiences and lessons learned. J Nutr 2002;32:S8568 .

25. Uauy R, Hertrampf E, Reddy M. Iron fortification of foods: overcoming technical and practical barriers. J Nutr 2002;132:S849-52.

26. Atamna H, Killilea DW, Killilea AN, Ames BN. Heme deficiency may be a factor in the mitochondrial and neuronal decay of aging. PNAS 2002;99:14807-12.

27. Morava E, Rodenburg R, van Essen ZH, Vries MD, Smeitink J. Dietary intervention and oxidative phosphorylation capacity. J Inherit Metab Dis 2006;29:589. 